Metal-Catalyzed

Asymmetric

Synthesis and

Stereoselective

Reactions

\section{Au-Catalyzed Diastereoselective [3+2] Cycloaddition}

\section{Key words}

\section{gold}

[3+2] cycloaddition allenyl ethers<smiles>O=CC1=CCPC=PC1</smiles><smiles>COC=CCCCCO</smiles>

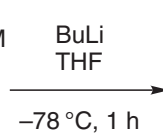

$\mathrm{R}^{1}=\mathrm{Me}$

$\mathrm{R}^{2}=\mathrm{H}, \mathrm{Ph}$

otherwise: $\mathrm{R}^{1}-\mathrm{R}^{2}=-\mathrm{CH}_{2}\left(\mathrm{CH}_{2}\right)_{n} \mathrm{CH}_{2}$ - where $\mathrm{n}=2-4$ or $-\mathrm{CH}_{2} \mathrm{CH}_{2} \mathrm{CH}\left[(R)-\mathrm{C}(\mathrm{Me}) \mathrm{CH}_{2}\right] \mathrm{CH}_{2}$ - [(-)-perillaldehyde]

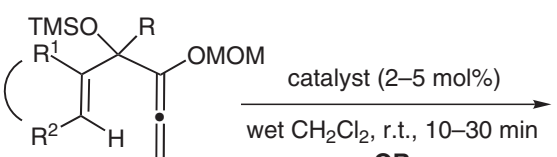

OR

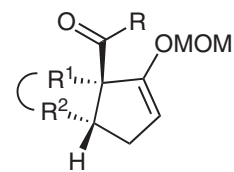

anhyd $\mathrm{CH}_{2} \mathrm{Cl}_{2}+$

$\mathrm{AcOH}\left(2\right.$ equiv), $0^{\circ} \mathrm{C}, 10-30 \mathrm{~min}$ single diastereomer

9 examples $44-99 \%$ except $\mathrm{dr}=1: 1$ for $(-)$-perillaldehyde]

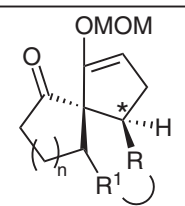

single diastereomer

(*-opposite enantiomer at this position for $\mathrm{R}^{1}-\mathrm{R}=-\mathrm{CH}_{2} \mathrm{CH}_{2} \mathrm{CH}_{2}-$ )

otherwise, $\mathrm{R}^{1}-\mathrm{R}=-\mathrm{CH}_{2} \mathrm{CH}_{2} \mathrm{CH}_{2}$ $\mathrm{AcOH}$ ( 2 equiv), $0^{\circ} \mathrm{C}, 10-30 \mathrm{~min}$

3 examples $79-90 \%$

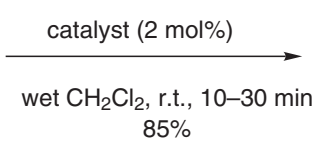
$85 \%$

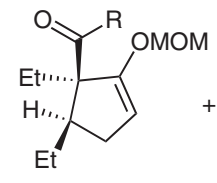

2.81
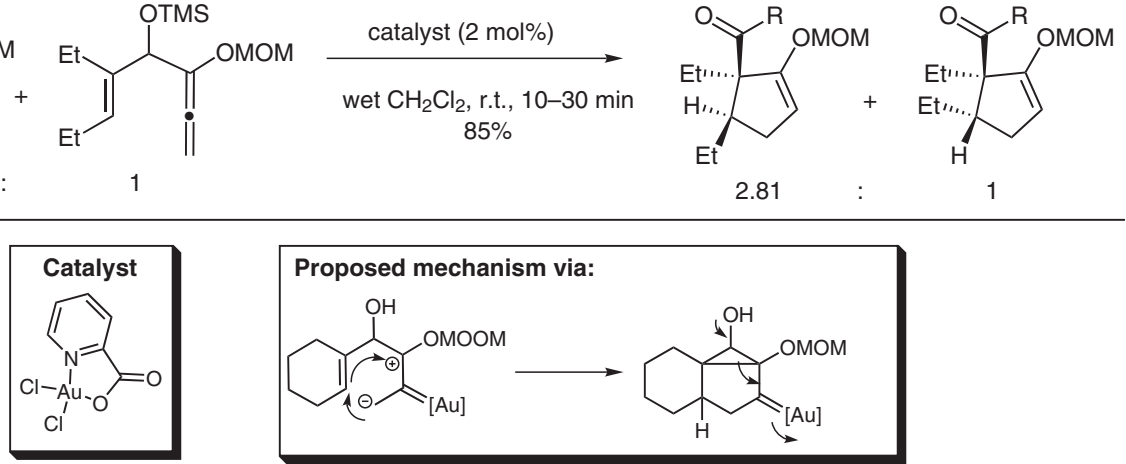

Significance: A gold-catalyzed diastereoselective [3+2] cycloaddition of an allenyl MOM ether with enals or enones is shown to create synthetically useful cyclopentanone enol ethers with all-carbon quaternary centers. The one-pot, two-step reaction first involves silylation of the enal or enone (which increases selectivity) followed by cycloaddition, eliminating the isolation of the delicate intermediate. The scope is broad for both acyclic and cyclic enals and enones with single diastereomers seen.
Comment: This is the first report of Au-activated allenes acting as 1,3-dipoles in [3+2] cycloadditions. In some cases, dichloromethane with water (as the proton source) was ideal for high yields, and in others, anhydrous dichloromethane with acetic acid was better. The mechanism is thought to occur in a concerted fashion and this is supported by the reaction of a mixture of Z/E allenes, which gave the corresponding diastereomeric aldehydes in roughly the same ratio as the starting mixture.

SYNFACTS Contributors: Mark Lautens, Praew Thansandote Dol: 10.1055/s-2007-968729; Reg-No.: L07807SF 